\title{
Choice of perching sites by East Asian robber flies (Diptera: Asilidae)
}

\author{
JOACHIM HAUPT* \\ University of the Ryukyus, Tropical Biosphere Research Center (Iriomote Station), 870 Uehara, Taketomi-cho 907-15, \\ Okinawa-ken, Japan; e-mail: hptjeiic@sp.zrz.tu-berlin.de
}

Key words. Diptera, Asilidae, behaviour, biodiversity, tropical ecology

\begin{abstract}
Field observations in different habitats on the island of Iriomote (Yaeyama, Ryukyu, Japan) were carried out concerning their importance as perching sites of robber flies (Diptera, Asilidae), including the specialization of different species to varying microhabitats. Factors of mutual exclusion for the different species include spatial (horizontal and vertical), seasonal and behavioural factors. Some geographically widespread species prefer open areas, commonly used for agriculture, but endemic species are localized in the tropical forests of the lowlands, and afford that area the need for special protection.
\end{abstract}

\section{INTRODUCTION}

Robber flies are among the most conspicuous Diptera, with the vast majority of species prefering open landscapes (Hull, 1962). While perching for prey, they sit on bare soil, on stones or on branches of trees and bushes. Some asilid species potentially compete for prey, and, therefore, the choice of perching sites is a prime factor for competing.

Ecological niches and perching sites of asilid imagines have mainly been studied in Russia and Middle Asia (Lehr, 1980), in Central America (Shelly, 1985) and in South Africa (Londt, 1994).

The study reported here relates the perching behaviour of some East Asian robber fly species to selected habitats and microhabitats, and discusses the ecological consequences of this. To assemble the data needed, when, where, and under which circumstances robber flies of different species perched was monitored.

Iriomote is an ideal place for such a study because a number of habitats can be found near one another. Originally, the island was almost completely covered by forests, ranging from tropical lowland forests and Barringtonia swamps in coastal areas, to broadleaf Castanopsis forests occurring at higher elevations. After extensive logging of native forests and the subsequent planting of Pinus luchuensis Mayr, most parts of Iriomote are now covered by secondary forests consisting of Castanopsis, which forms the climax vegetation at altitudes above coastal forests. At various times over the past one hundred years, the cultivated areas on the island have increased at the expense of tropical lowland forests (Takara \& Azuma, 1970).

The paper addresses whether and how ecological specialization avoids food competition.

\section{MATERIAL AND METHODS}

Perching behaviour of Asilid flies was observed in the field on the island of Iriomote (Yaeyama, Ryukyu, Japan) over three seasons, from April 1995 to July 1999. The following habitats were included in the study: sandy and rocky shore, lowland forest, mountain forest between 50 and $250 \mathrm{~m}$, pine apple plantations and adjoining hedges. To make observations comparable the same time effort was expanded on specific trails, each about $1000 \mathrm{~m}$ long, which were searched for asilids. Specimens were considered to be active when they were observed perching.

As Asilid specimens are more or less stationary at their perching sites, this method of observation by and large avoids counting the same specimens more than once. The time spent observing in different habitats and during different times of the year was nearly equal.

An area of $400 \mathrm{~m}^{2}$ was observed for Clinopogon sauteri and specimens passing the bounderies were counted to determine the activity of this species. Nevertheless, the relatively rare occurrence of some species and the inability to observe them in unfavourable wheather conditions (rainy days, typhoon), resulted in some record gaps (Fig. 1), and necessitated the omission of species with less than 10 observations (Molobratia triangulata, Scylaticus sayano, and Astochia fallaciosus) from further detailed consideration. The observations were classified according to time, habitat, and microhabitat.

Temperature measurements were made at the exact site of asilid perching using an electric Delta thermometer (Sato Keiryoki, Japan) and the testo ${ }^{\circledR} 610$ by ecotech (Bonn), which also measures relative humidity. Recording by a kymograph (Lambrecht, Göttingen) was carried out in the different biotopes. Daily changes in temperature and relative humidity vary in a characteristic way when comparing lowland forests and open fields: variations inside forests are very limited $\left(4-5^{\circ} \mathrm{C}\right.$ between day and night, with a relative humidity around $90 \%-$ except during strong winds, when asilids are not active. In the fields a daily temperature fluctuation was observed which shows a minimum in the early morning and a $10-12^{\circ} \mathrm{C}$ higher maximum at noon, corresponding with a minimum in relative humidity of about $50 \%$ which gradually increased through the late evening to about $90 \%$. Thus, only small temperature differ-

\footnotetext{
* Corresponding address: Institut für Ökologie, Technische Universität Berlin, FR 1-1, Franklinstraße 28/29, D-10587 Berlin, Germany.
} 
TABLE 1. Occurrence of specimens of different species in different perching sites, $\mathrm{n}$ number of observations.

\begin{tabular}{|c|c|c|c|c|c|c|c|c|c|c|c|c|c|c|c|c|c|}
\hline Biotop & Beach & & & Field & & & & & Forest & & & & & Mangr & oves & & \\
\hline $\begin{array}{l}\text { Species } \\
\text { (n number of } \\
\text { specimens } \\
\text { observed) }\end{array}$ & $\begin{array}{r}\text { sand } \\
\text { beach }\end{array}$ & $\begin{array}{l}\text { rocky } \\
\text { shore }\end{array}$ & $\begin{array}{l}\text { bare } \\
\text { ground }\end{array}$ & $\begin{array}{l}\text { stalks, } \\
\text { twigs }\end{array}$ & $\begin{array}{c}\text { grass } \\
\text { blades }\end{array}$ & $\begin{array}{c}\text { leaves } \\
\text { of } \\
\text { bushes } \\
<1.0 \mathrm{~m} \\
\end{array}$ & $\begin{array}{l}\text { leaves } \\
\text { of } \\
\text { bushes } \\
>1.0 \mathrm{~m}\end{array}$ & $\begin{array}{c}\text { leaves } \\
\text { of } \\
\text { bushes } \\
>1.8 \mathrm{~m} \\
\end{array}$ & $\begin{array}{l}\text { bare } \\
\text { ground }\end{array}$ & $\begin{array}{l}\text { stalks, } \\
\text { twigs }\end{array}$ & $\begin{array}{c}\text { leaves } \\
\text { of } \\
\text { bushes } \\
<1.0 \mathrm{~m} \\
\end{array}$ & $\begin{array}{l}\text { leaves } \\
\text { of } \\
\text { bushes } \\
>1.0 \mathrm{~m} \\
\end{array}$ & $\begin{array}{c}\text { leaves } \\
\text { of } \\
\text { bushes } \\
>1.8 \mathrm{~m} \\
\end{array}$ & stems & $\begin{array}{c}\text { leaves } \\
\text { and } \\
\text { roots } \\
<1.0 \mathrm{~m} \\
\end{array}$ & $\begin{array}{l}\text { leaves } \\
\text { and } \\
\text { roots } \\
>1.0 \mathrm{~m} \\
\end{array}$ & stems \\
\hline $\begin{array}{l}\text { Clinopogon } \\
\text { sauteri (45) }\end{array}$ & 45 & & & & & & & & & & & & & & & & \\
\hline $\begin{array}{l}\text { Machimus } \\
\text { asiaticus } \\
\text { (20) }\end{array}$ & & 2 & 4 & & & & & & 8 & 1 & 5 & & & & & & \\
\hline $\begin{array}{l}\text { Cophino- } \\
\text { poda } \\
\text { chinensis } \\
\text { (41) }\end{array}$ & & & & 27 & 14 & & & & & & & & & & & & \\
\hline $\begin{array}{l}\text { Microstylum } \\
\text { dimorphum } \\
(42)\end{array}$ & & & & 2 & 2 & 8 & 21 & 2 & & & 4 & 3 & & & & & \\
\hline $\begin{array}{l}\text { Orophotus } \\
\text { univittattus } \\
\text { (34) }\end{array}$ & & & & & & & & & & 26 & 8 & & & & & & \\
\hline $\begin{array}{l}\text { Astochia } \\
\text { philus (15) }\end{array}$ & & & & & & & & & & 14 & 1 & & & & & & \\
\hline $\begin{array}{l}\text { Merodontina } \\
\text { silvatica ( } 75)\end{array}$ & & & & & & & & & & 4 & 33 & 36 & 2 & & & & \\
\hline $\begin{array}{l}\text { Choerades } \\
\text { yaeyamana } \\
(58)\end{array}$ & & & & & & & & & & & 34 & 22 & 2 & & & & \\
\hline $\begin{array}{l}\text { Promachus } \\
\text { indigenus } \\
\text { (66) }\end{array}$ & & & 6 & 3 & 5 & 4 & 2 & 2 & 4 & 11 & 18 & 6 & & 5 & & & \\
\hline $\begin{array}{l}\text { Choerades } \\
\text { aenea (22) }\end{array}$ & & & & & & & & & & & & & & & 10 & 4 & 8 \\
\hline
\end{tabular}

ences were recorded from different microhabitats, consequently, these were not considered to be important differential factors.

An ELVOS (Germany) LM-1010 Luxmesser was used to mesure light intensity. The results varied between an average of 4300 Lux in forests and an average of 39500 Lux in the fields.

The few asilid species observed could be readily distinguished in the field without any interference in their natural behaviour. Nevertheless, some specimens finally had to be taken as reference material and for determination. Species were determined according to Engel (1938), and original descriptions by Becker (1925), Enderlein (1914), Hermann (1914), Matsumura (1916) and Nagatomi (1983). According to the relative isolation of the Yaeyama islands between Taiwan and Okinawa, some asilid species were new. These were described in a separate paper (Haupt \& Azuma, 1998).

\section{RESULTS}

The registration of asilid imagines will be considered first under the temporal aspect. Whereas several asilid species occur during an extended time in spring and summer, others have been found only during a rather limited period. Concerning different species the number of specimens observed has been plotted against time (months of the year) (Fig. 1).

Another parameter is the spatial (horizontal and vertical) distribution in the study area, which is summarized in an idealized catena in relation to altitude and vegetation (Fig. 2). The figure clearly demonstrates that the majority of asilid species inhabits the lowland tropical forests up to an altitude of about $50 \mathrm{~m}$.
The use of different perching sites ranges from beach and ground level to herb, bush and tree strata (Fig. 3), but the exclusiveness of certain microstructures used by different species varies to a certain degree (Table 1). Mainly four groups of species can be distinguished: geophilous species (A, B), the majority of silvicolous species with preferences for herbs and bushes (C-F), one tamnobiont species $(G)$ choosing mostly the stem of trees (in our case mangroves), but also branches and roots in younger groves for perching, and herbiphilous species of the open landscape $(\mathrm{I}, \mathrm{K})$.

The preferences of perching sites by asilid imagines of different species are listed starting from the beach and ground level and proceeding to the herb, bush and tree strata:

1. Clinopogon sauteri Bezzi, 1910 occurs only during summer (Fig. 1A) on bare sand of beaches (Fig. 2A), where it flies around at an altitude of a few centimeters, sometimes settling for a rest on the sand, on flat rocks on the beach, or rarely on small objects lying on the sand. Rocks surrounding the beaches are rarely used for perching. C. sauteri is the only species in which a clear relationship between temperature and activity could be registered. During sunny summer days a considerable increase in temperature at the sand surface is correlated with the species' activity (Fig. 4).

2. Machimus asiaticus Becker, 1925 (Fig. 1B, 2B), occurs during spring. It is mostly limited to bare soil 
A

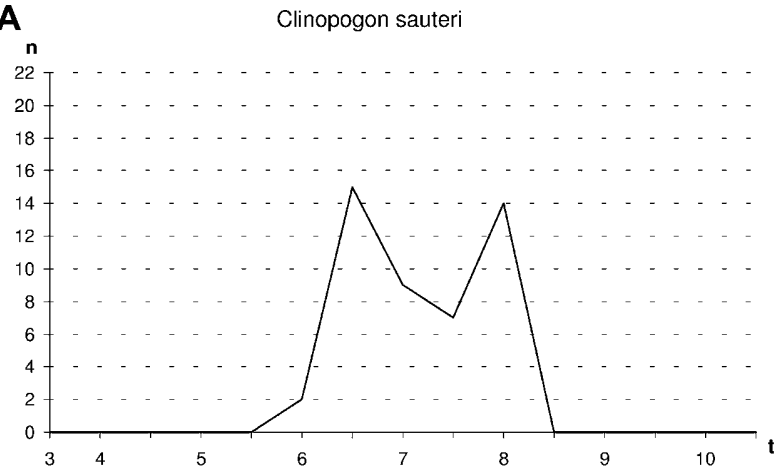

B

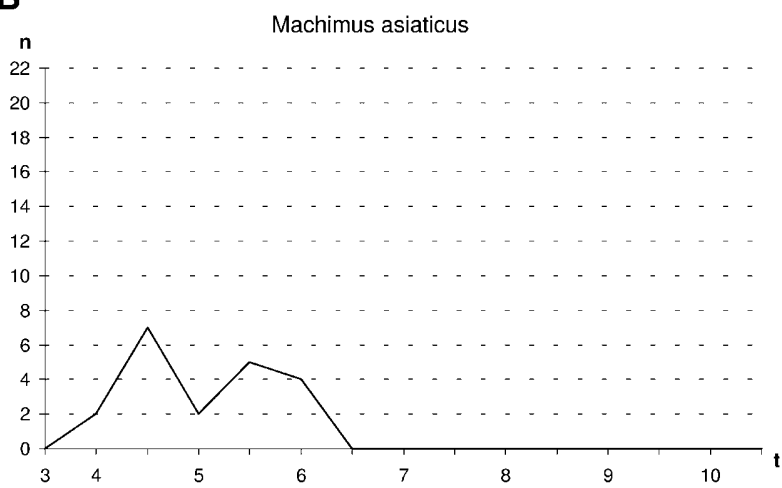

C

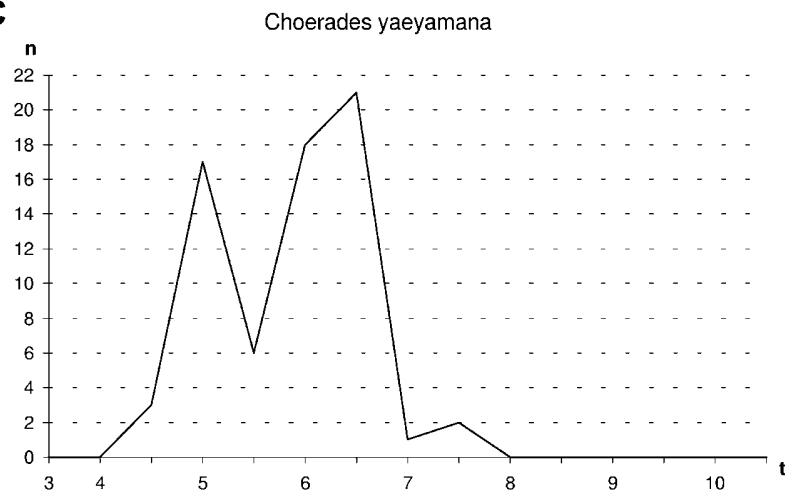

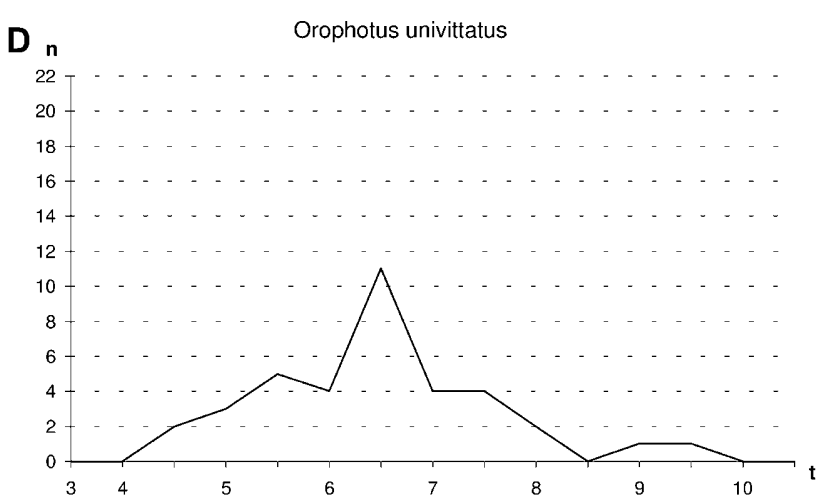

E n

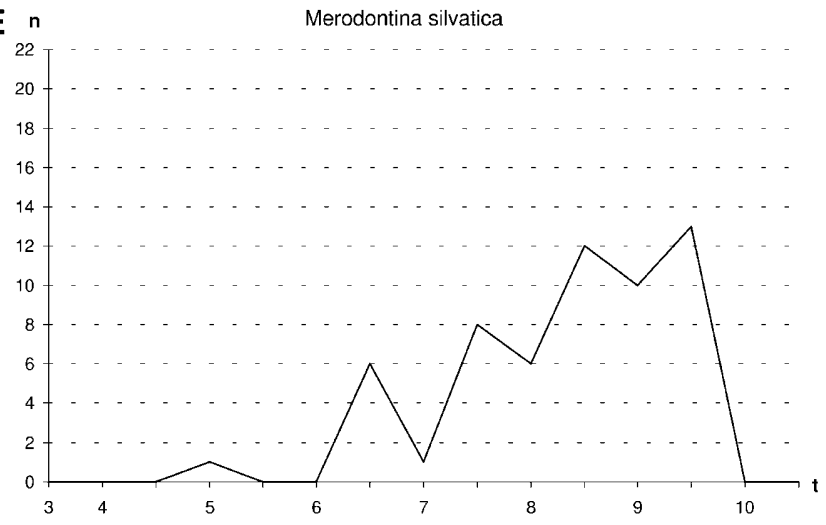

F n Astochia philus

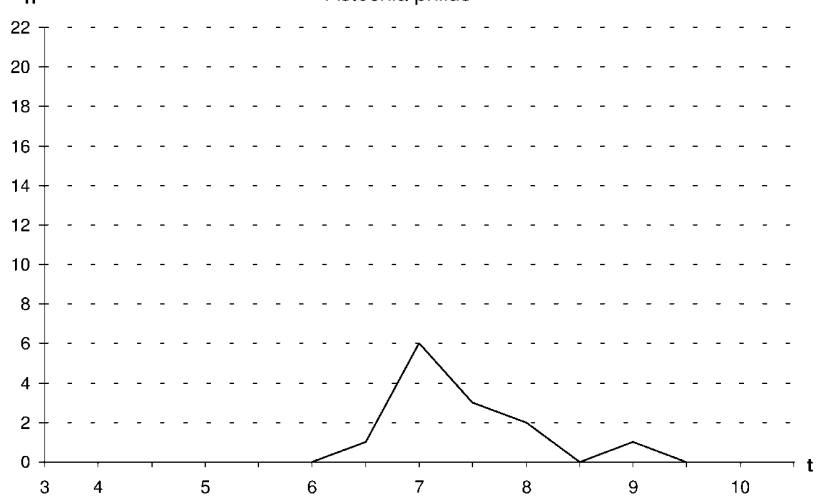

Fig. 1. Phenology of more abundant asilid imagines (number of individuals plotted against months of the year). A - Clinopogon sauteri; B - Machimus asiaticus; C - Choerades yaeyamana; D - Orophotus univittatus; E - Merodontina silvatica; $\mathrm{F}$ - Astochia philus.

along the coast line, as well as to eroded bare land adjoining plantations, and even small pads of bare soil within the forest. It generally perches on the bare soil, but it is rarely found perching on small objects on the ground (pieces of coral debris, pebbles, dry leaves). This species was not found perching on roads in agricultural areas or in mangrove swamps. At the beginning of June a few females were found in the lowland forest.

3. Astochia fallaciosus (Matsumura, 1916) was observed close to the beach during August, but inside the coastal forest, perching on herbs and twigs in the herbal stratum. Because of very limited data, this species was omitted from further discussion.
4. Choerades yaeyamana Haupt \& Azuma, 1998 (Fig. $1 \mathrm{C}, 2 \mathrm{C}$ ), is a very abundant, black species. In the morning and afternoon it is found on bushes at the shore or grassy lowland swamps in the coastal forest. There, it perches on leaves from 1.2 up to $1.8 \mathrm{~m}$ height. Most of the day specimens were in shaded areas, close to the moist forest floor of coastal and lowland forest (5-50 m alt.). It perches on fern fronds and leaves $0.2-0.5 \mathrm{~m}$ high. With increasing altitude (highest observation at clearing in Castanopsis forests at about $250 \mathrm{~m}$ alt.), this species becomes rare.

5. Orophotus univittatus Becker, 1925, (Fig. 1D, 2D), is found in the Castanopsis forests at low altitudes (up to $40 \mathrm{~m}$ ), often in the neighbourhood of Barringtonia swamps or brooklets, waiting for prey on bare, dead 

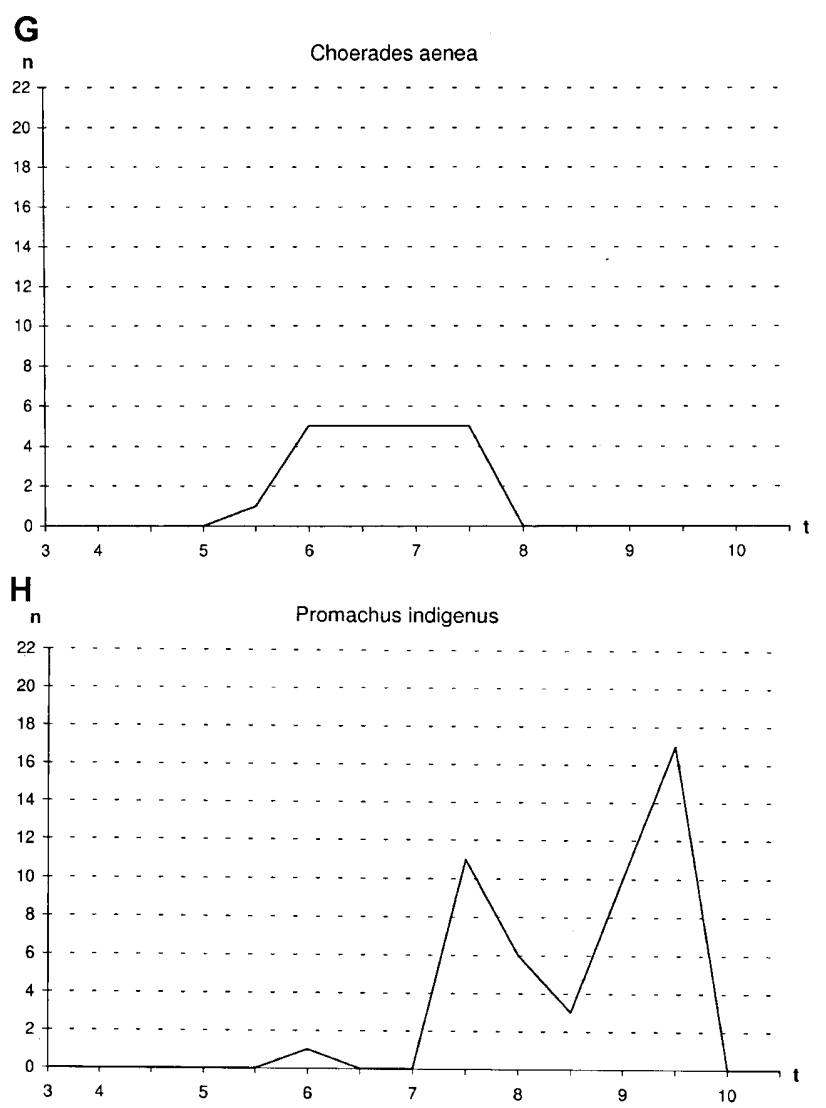

$I_{\text {n }} \quad$ Cophinopoda chinensis
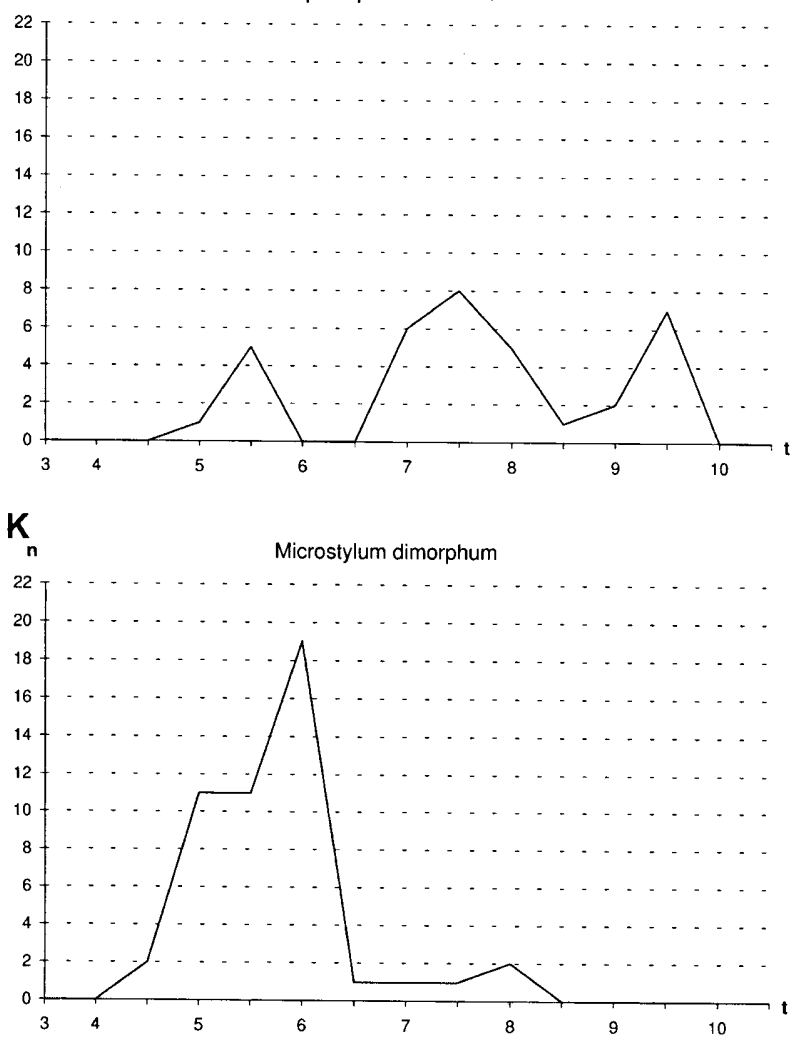

Fig. 1. Phenology of more abundant asilid imagines (number of individuals plotted against months of the year). G-Choerades aenea; $\mathrm{H}$ - Promachus indigenus; I - Cophinopoda chinensis; $\mathrm{K}$ - Microstylum dimorphum. twigs, or bare stalks of fern, close to the ground (0.2-0.5 $\mathrm{m})$. It perches with the plain of its body parallel to the twigs. When disturbed, flies of this species return to the same twig after a short time, even though dry branches are plentiful in the area. This provides evidence that $O$. univittatus individuals maintain a territory of about 3-5 $\mathrm{m}^{2}$ whithin which they perch, feed and mate.

6. Only very few specimens of Molobratia triangulata Haupt \& Azuma, 1998 were found in the herb stratum of Castanopsis forests. Within that forest, they perched on fern fronds or leaves that were close to the ground $(0.15-$ $0.50 \mathrm{~m})$.

7. Merodontina silvatica Haupt \& Azuma, 1998 (Fig. 1E, 2E). During the spring very few specimens were observed, but during summer this species occurs throughout the forest at altitudes to and about $250 \mathrm{~m} . M$. silvatica perches on leaves or fern fronds, mostly between 1.2 and $1.8 \mathrm{~m}$ above ground in clearings in the forest.

8. Astochia philus (Walker, 1878) was observed in coastal forests, perching on bare twigs (Fig. 1F, 2F). Apparently, the same individuals were observed at the same site several times, but only during the morning hours when the site was in full sun.

9. Choerades aenea (Fabricius, 1805) (Fig. 1G, 2G) is found during the summer perching on the stems of large mangrove trees (Bruguiera). The flies sit head foremost observing the area beneath them. On younger mangroves, the flies perch on leaves or roots overhanging small tidal creeks.

10. Promachus indigenus Becker, 1925 (Fig. 1H, 2H) is a very abundant species occurring mainly from July to September, when most other species have disappeared. It is remarkably euryoecious, using many different habitats and structures for perching (Table 1). These range from the edge of hedges in the field (but not in the open field), to roads and paths, but this species also occurs inside the forests. Shortly after emerging, specimens are limited to the bush stratum, perching on branches and leaves. Under these circumstances they were observed in habitats of Miscanthus sinensis and ferns, mixed with acacia bushes and isolated trees (ca. $200 \mathrm{~m}$ alt.).

The following species are perching in the herb and bush stratum of the open landscape, and locally they are found quite abundant.

11. Cophinopoda chinensis (Fabricius, 1794) (Fig. 1I, $2 \mathrm{I}$ ), is an abundant species hunting in ruderal areas, as well as in adjoining pineapple fields rich in weeds. Specimens often settle on the stalks of these plants or on grass blades $0.2-0.4 \mathrm{~m}$ above ground.

12. Microstylum dimorphum Matsumura, 1916 (Fig. $1 \mathrm{~K}, 2 \mathrm{~K}$ ) is a large species of about $40 \mathrm{~mm}$ length, hunting mostly in ruderal places, pineapple fields, and adjoining hedges. The flies generally perch on stalks of herbs $0.4-$ $0.7 \mathrm{~m}$ above ground or up to $1.7 \mathrm{~m}$ high on leaves at the outer parts of hedges. Single males regularly cover an area of about $10000 \mathrm{~m}^{2}$ using a characteristic style of 
TABLE 2. Diagram of mutual exclusion. Exclusion factors: beh behavioural by choosing different microhabitats, hor horizontal (distribution in different habitats), sea seasonal, siz presumably different spectrum of prey according to largely differing siz e, vrt vertical (distribution in different strata by choosing varying microhabitats or different height above ground).

\begin{tabular}{|c|c|c|c|c|c|c|c|c|c|}
\hline Species & Cl.s. & Ma. a. & Ch. $y$. & Or.u. & Mo.t. & Pr. i. & Me.s. & Ch. a. & Co.c. \\
\hline Clinopogon sauteri & - & & & & & & & & \\
\hline Machimus asiaticus & sea & - & & & & & & & \\
\hline Choerades yaeyamana & hor/vrt & vrt & - & & & & & & \\
\hline Orophotus univittatus & hor/vrt & hor/vrt & vrt & - & & & & & \\
\hline Molobratia triangulata & hor/vrt & hor/vrt & hor? & sea/beh? & - & & & & \\
\hline Promachus indigenus & hor & sea/siz & sea/siz & sea/hor & sea & - & & & \\
\hline Merodontina silvatica & hor/vrt & hor/vrt & vrt & beh & $\operatorname{siz} ? / \mathrm{vrt}$ & $\operatorname{siz}$ & - & & \\
\hline Choerades aenea & hor/vrt & sea/vrt & hor/vrt & hor/vrt & sea/hor/vrt & hor/vrt & hor/vrt & - & \\
\hline Cophinopoda chinensis & hor/vrt & hor/vrt & hor & hor & hor & hor & hor/vrt & hor/vrt & - \\
\hline Microstylum dimorphum & hor/vrt/siz & hor/vrt/siz & hor/siz & hor/siz & hor/siz & sea/hor/siz & hor/siz & hor/vrt & $\operatorname{siz} /(\mathrm{vrt})$ \\
\hline
\end{tabular}

flight that follows a rather straight line in a sinusoidal up and down movement, apparently in search of females. Copulation occurs on the lower parts of herbs, about 0.3 $\mathrm{m}$ above the ground. Single females were still observed at the end of July and the beginning of August (Fig. 1K), but at that time they are found in the forest, possibly engaged in the deposition of eggs. A large number of freshly emerged flies (males not yet fully coloured and cuticle still rather soft) were also observed in the forest at the beginning of June.

13. Scylaticus sayano Nagatomi, 1983. A few specimens of this species were observed in ruderal and agricultural habitats together with Microstylum.

In some habitats it was very obvious that certain species like Microstylum dimorphum, Cophinopoda chinensis, and Clinopogon sauteri were only found in specific places, and this fact was more striking in abundant species of open fields and the beaches. Some species that live in forests, such as Choerades yaeyamana, Merodontina silvatica, and Orophotus univittatus, seem to be more evenly distributed.

\section{DISCUSSION}

\section{Ecological classification of asilids according to imaginal habitats}

There have been previous efforts to classify robber flies according to their habitats (Lehr, 1980, Shelly, 1985, Londt, 1994). Basically, such classifications may distinguish species that inhabit open areas from those that inhabit forests. The distinction of light and shade-seeking asilid species in Central America (Shelly, 1984) could also be applied in general to species observed in Iriomote, but few species (e.g. Microstylum dimorphum and Machimus asiaticus) can change their behaviour depending on whether they are in a perching or egg deposition mode. Promachus indigenus changes habitats, too.

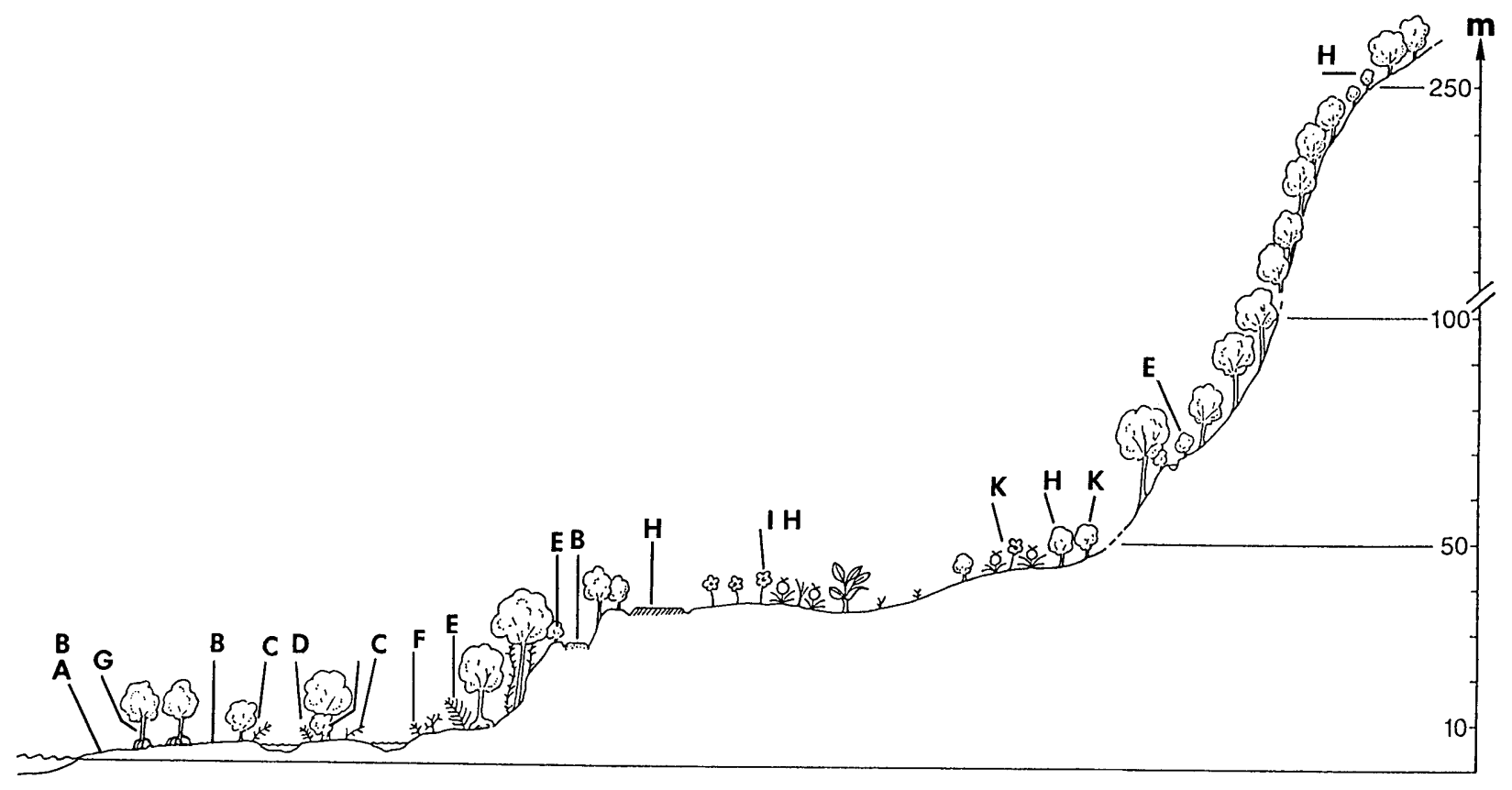

Fig. 2. Schematic catena of different biotopes on Iriomote island with habitats of asilid species. A - Clinopogon sauteri; B Machimus asiaticus; C - Choerades yaeyamana; D - Orophotus univittatus; E - Merodontina silvatica; F - Astochia philus; G Choerades aenea; $\mathrm{H}$ - Promachus indigenus; I - Cophinopoda chinensis; $\mathrm{K}$ - Microstylum dimorphum. 


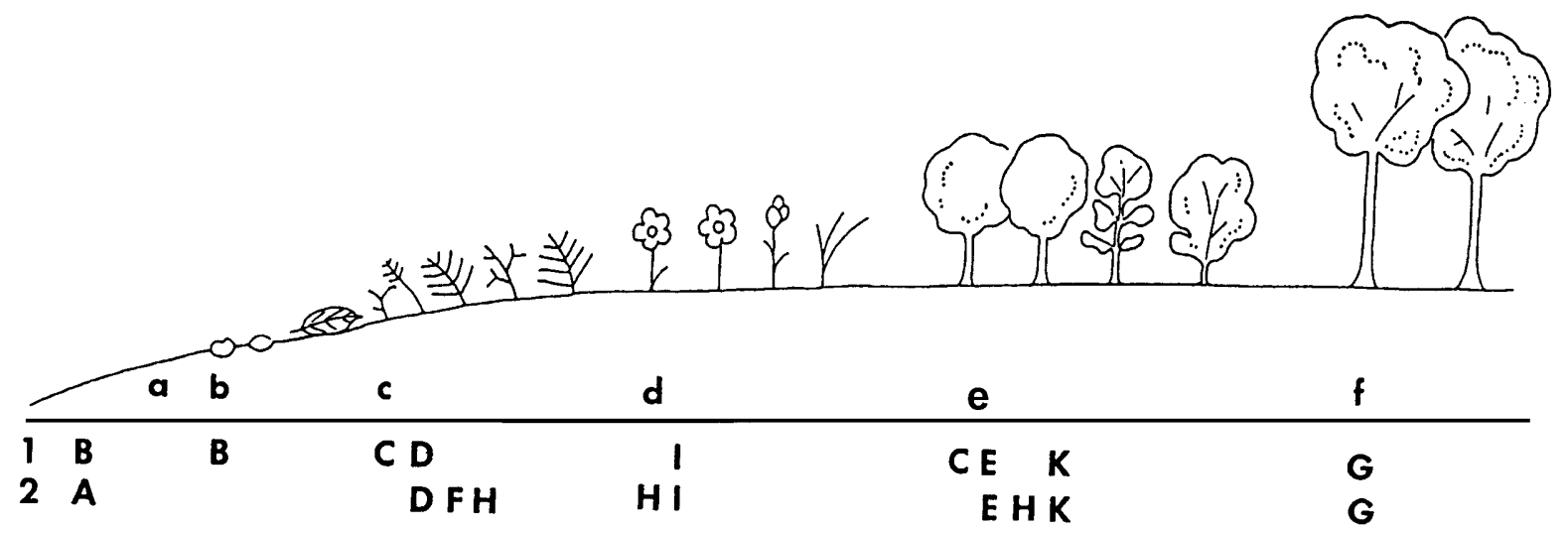

Fig. 3 Synopsis of ecological microstructures and microhabitats used by different asilid species during spring (1) and summer (2). $\mathrm{a}$ - bare soil; $\mathrm{b}$ - stones, corral debris and dry leaves; $\mathrm{c}$ - dry twigs, bare fern stalks or fern fronds; $\mathrm{d}$ - herbs or grass; $\mathrm{e}-\mathrm{bushes;} \mathrm{f}-$ trees (in this case mangroves). A - Clinopogon sauteri; B - Machimus asiaticus; C - Choerades yaeyamana; D - Orophotus univittatus; E - Merodontina silvatica; F - Astochia philus; G - Choerades aenea; H - Promachus indigenus; I - Cophinopoda chinensis; $\mathrm{K}$ - Microstylum dimorphum.

During the time shortly after emerging, the flies are found in areas close to their larval habitats. Following a long period of imaginal dispersal they then inhabit a great number of different areas (Fig $2 \mathrm{H}$, Table 1). Therefore, light is the factor that seems of minimal importance to this species, although Promachus indigenus is generally not found in the open fields.

In the Yaeyama Islands most asilid species inhabit the area from the seashore to altitudes of about $50 \mathrm{~m}$ (Fig. 2). Most species are found in forested zones, and they are indigenous. This corresponds to the fact that this region was originally covered by tropical plants (Niiro et al., 1974). Silvicolous asilids seem to be rather limited now. Their mobility between different islands is limited, because forest continuity is lacking since the Pleistocene era.

Species of the open landscape may have to be considered ubiquists, mostly colonizing areas used for agriculture. Two of the three species characteristic for the latter habitat (Microstylum dimorphum, Cophinopoda chinensis) occur also in Okinawa, and the latter species is even widespread in East Asia.

During the study of asilids in Iriomote, all species living in the forest or at its edge occupied specific niches. Only in a few cases, discussed below, were these temporarily overlapping, and at some localities, up to four species could be observed in relatively close proximity. This may hint at a longstanding ecological specialization, apparently also related to the choice of perching positions.

\section{Ecological classification according to microhabitats}

A more detailed ecological distinction of asilid imagines takes into account perching on different strata: ground, herb, bush and tree stratum. In the Palaearctic (Lehr, 1980), as well as in the Afrotropical Region (Londt, 1994) and the Mesoamerican Region (Shelly, 1985), efforts have been undertaken to relate asilid species to certain microhabitats.
Similar specialisations on specific microhabitats are also observed in Iriomote (Table 1). Although Merodontina silvatica prefers to perch on leaf surfaces, the choice by Orophotus univittatus of dry, bare twigs close to the ground or of bare fern stalks positions the predator rather close to the soil surface, without the interference of neighbouring leaves. The regular positioning parallel to the stem is also practized by species occurring in other faunal regions, e.g. in Central America (Fisher \& Hespenheide, 1992).

The only tamnobiont (hunting from trees) species found so far in Iriomote is Choerades aenea, occupying mangrove swamps and wide spread in East Asia. This species can adapt to changing conditions as demonstrated by its ability to perch on roots and lower branches in young groves.

The number of possible microhabitats has gradually increased (Londt, 1994), and the most sophisticated classification attempts to relate places of perching to hunting territories (Lehr, 1980). Nevertheless, such a system may not be generally applicable, because there are species that transgress these boundaries, and the hunting areas may be more related to prey availability and therefore more variable. Moreover, choice of perching sites may be related to species richness in a certain habitat. For such reasons it seems nearly impossible to combine a classification of perching sites with that of actual hunting areas.

For statistical reasons Shelly (1965) dealt with only 15 of about 65 species in Central America. This study may therefore add little information to the question on mechanisms of partitioning available microhabitats by different asilid species. A general problem exists of how to deal with species, that do not occur in large numbers. Certainly, these species that are encountered infrequently are important ecologically and contribute to the overall stability of the ecological system. Londt (1994) reported 25 species in 14 genera from a single site in the Cape Province. Such higher density of species would result in a stronger evolutionary pressure for specialization. The asilid fauna of Iriomote is much poorer. During the pre- 


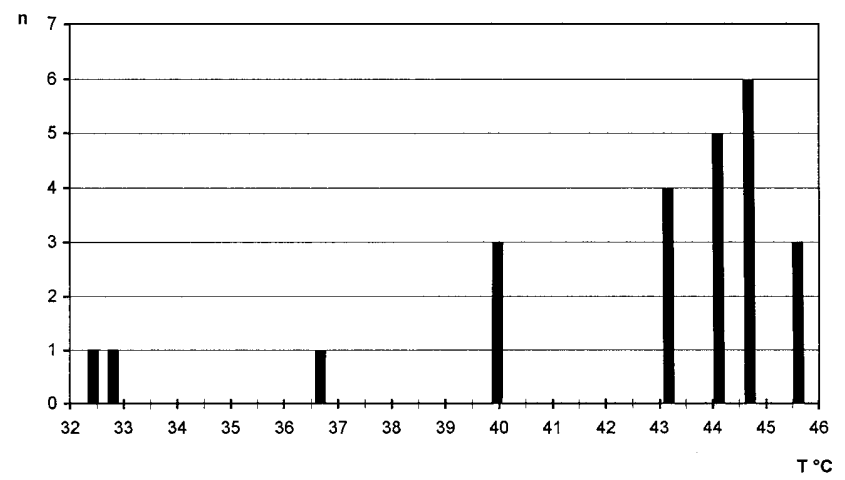

Fig. 4 Activity of Clinopogon sauteri as related to the temperature of the sand surface $\left(\mathrm{T}^{\circ} \mathrm{C}\right), \mathrm{n}$ number of observations.

sent study 13 species were observed. Two more species have previously been observed on Iriomote, and five more species are known from Okinawa and from Taiwan (Haupt \& Azuma, 1998), but these species were not recorded during the present study. This may be due to the limited number of sites that could be patrolled regularly. In any case, a lower species density may at least in part, explain less stringent ecological specialization. Thus, Promachus indigenus, which is abundant comparatively late in the year, shows the least ecological specialization concerning perching sites (Table 1., Fig. 2H), possibly resulting from the lack of competition from other asilid species.

\section{The role of temperature and relative humidity in the microhabitat}

Temperature measurements at the perching site suggest that thermal related behaviour is not evident for most species. This may be not surprising, as the temperatures do not fluctuate greatly in the coastal forest zone, nor in the open landscape, where the daily rise in temperature is eased by wind from the sea. Consequently, there is no evidence for thermal shifting linked to thermoregulation, as has been reported by O'Neill \& Kemp (1992) from sympatric asilids in different grassland microhabitats.

But temperature clearly plays a role in the diurnal activity of the beach dwelling Clinopogon sauteri. The higher temperature observed in the microhabitat is sufficient to explain the increased activity during the afternoon (Fig. 4) and the lack of activity during the morning hours.

The daily cycle of relative humidity may influence the behaviour of certain silvicolous species. Preference of Orophotus univittatus for moist environments may be reflected by their more frequent occurrence in the neighbourhood of small brooks, creeks, and swamps. Contrary to this, Merodontina silvatica occurs in drier parts of the forest, and also at higher elevations. In the lowlands Molobratia triangulata is a close neighbour of Orophotus univittatus. According to the few observations that were made, it occupies areas in the neighbourhood of Barringtonia swamps, perching on low leaves and fern fronds.

The distribution of Choerades yaeyamana is clearly influenced by humidity changes. Whereas specimens of Choerades yaeyamana may be observed in more exposed habitats during the morning and late afternoon, more specimens are observed in the coastal forests around noon, when the microclimate is more moist than in places fully exposed to the sun. Beyond the availability of prey, relative humidity may be a limiting factor for inhabiting heigher zones. When conducted, laboratory experiments will provide evidence to resolve such questions.

\section{Prey competition}

Do mechanisms exist to reduce competition for prey among different species of asilids, and if so, what are they?

Species that perched in the open landscape, (i.e. Cophinopoda chinensis, Microstylum dimorphum and Scylaticus sayano) were often not hunting in identical areas, although at some localities a slight overlap in hunting areas has occurred. The extraordinarily different body size $(20 \mathrm{~mm}$ and stout, $35 \mathrm{~mm}, 17 \mathrm{~mm}$ and slender, respectively) makes competition for prey targets unlikely. Besides that, Cophinopoda chinensis is a chortobiont in the sense of Lehr (1979), i.e., hunting in the herb stratum, while Microstylum dimorphum hunts mostly along bushes in the open air. Scylaticus sayano seems to hunt inside the bushes, but only few observations could be made of this species. Thus, hardly any competition for food among these three species can be expected.

Both geophilous species (Machimus asiaticus and Clinopogon sauteri) exclude one another because of a differing imaginal phenology (Fig. 1, Table 1). Clinopogon sauteri perches during summer on sand, and is limited to full sun on the beaches. Machimus asiaticus imagines appear earlier in the year and patrol bare soil at the coast and within forests. Thus, mainly seasonal differences must be the decisive factor.

When comparing all species and summarizing the observations, the factors of mutual exclusion, factors that exclude different species from possible prey competition, appear quite variable, but it is obvious that certain factors are occurring more often than others (Table 2). Prey competition thus seems to be largely avoided among asilids.

\section{Discontinual distribution of asilid flies}

A specific choice of microhabitats may only partly explain a considerable discontinuity sometimes observed in the distribution of asilid populations (Hull, 1962). However, many apparently suitable habitats are not occupied by representatives of corresponding asilid species, therefore, the actual distribution must also be influenced by other factors, like habitats of larvae and sites of eclosion or microclimatic conditions and food supply.

The locally frequent occurrence of specimens of Cophinopoda chinensis could readily be explained from sites of larval development, e.g. a site sprayed with herbicides was not populated by this species during the following year, although flowering herbs with visiting potential prey were present again.

The occurrence of freshly emerged specimens of Microstylum dimorphum and later in the year of adult females of that species in the forest strongly suggests that forest habitats are used for egg deposition and represent 
the sites of larval development. In this case, the imaginal perching habitat would not be related to the area of eclosion. Even more obvious is the spreading of Promachus indigenus after eclosion.

Certainly, this problem cannot be solved without an intensive study of asilid larval biology.

ACKNOWLEDGEMENTS. The present study was made possible through an invitation by Monbusho C.O.E. to J.H. as a foreign visiting researcher to the Tropical Biosphere Research Center (Iriomote Station). I am greatly indebted to Prof. Dr. K. Yamazato for his constant promotion of research, to Prof. Dr. M. Aramoto, Prof. Dr. K. Fujimori and Prof. Dr. T. Takaso and their staff for offering their help in the Iriomote Station. Prof. M. Suwa, Prof. M. Sasakawa, and Dr. M. Yafuso kindly provided important Japanese literature. We thank Mr. W. Roloff for completing the drawings and Dr. J. Dunlop and an unnamed referee for improving the English text.

\section{REFERENCES}

Becker T. 1925: H. Sauters Formosa-Ausbeute: Asilidae III (Dipt.). Entomol. Mitt. 14: 62-85, 123-139, 240-250.

ENDERLEIN G. 1914: Dipterologische Studien. XI. Zur Kenntnis der tropischen Asiliden. Zool. Anz. 44: 241-263.

ENGel E. O. 1938: Asilidae. In Lindner E. (ed.): Die Fliegen der Palaearktischen Region, vol. IV 2. Schweizerbart'sche Verlagsbuchhandlung, Stuttgart, $491 \mathrm{pp}$.

Fisher E. M. \& HesPenheide H. A. 1992: Taxonomy and biology of Central American robber flies with an illustrated key to genera. In Quintero D. \& Aiello A. (eds): Insects of Panama and Mesoamerica: Selected Studies, Chapter 41. Oxford University Press, Oxford, New York, Tokyo. pp. 611-632.

Haupt J. \& Azuma S. 1998: Faunistic and taxonomic notes on robber flies (Diptera: Asilidae) from the Ryukyu Islands (Japan) with the description of three new species, Molobratia triangulata sp.n., Choerades yaeyamana sp.n. and Merodontina silvatica sp.n. Dtsch. Entomol. Z. 45: 33-42.

Hermann F. 1914: Sauters Formosa-Ausbeute. Mydaidae et Asilidae (Dasypogoninae, Laphrinae et Leptogastrinae). Entomol. Mitt. 3: 33-44, 83-95, 102-112, 129-136.
Hull F.M. 1962: Robber flies of the world. The genera of the family Asilidae. Smithsonian Inst., US Nat. Mus. Bull. 224: $1-907$.

LeHR P.A. 1979: On the direction of evolution (examplified by robber flies - Diptera: Asilidae). Far East Res. Centre, BiolPedol. Inst., Trudy (NS) 52: 20-57 (in Russian).

LEHR P.A. 1980: Being eurybiont - the first step in the evolution of a group (examplified by robber flies - Diptera: Asilidae). In Convergence and Direction in Insect Evolution. Acad. Sci. USSR, Far East Res. Centre, Biol-Pedol. Inst., Vladivostok, pp. 4-69 (in Russian).

LEHR P.A. 1991: Revision of the asilid genus Choerades Walker, 1851, and a note on the structure of the subfamily Laphriinae (Diptera: Asilidae). Entomol. Obozr. 70: 694-717 (in Russian).

LONDT J.G.H. 1994: Afrotropical Asilidae (Diptera). 26. Ethological aberrations and a possible ecological classification based on habitats. Ann. Natal Mus. 35: 97-112.

Matsumura S. 1916: New Iconographia of a Thousand Insects of Japan. Vol. 2. Keisei sha shoten, Tokyo. pp. 288-337 (in Japanese).

Nagatom A. 1983: The oriental Scylaticus (Diptera: Asilidae). Mem. Kagoshima Univ., Research Center South Pacific 3 (2): $142-162$.

Nimo Y., Mryagi K., Shinjo K. \& Shimabukuro H. 1974: Vegetation of the Yaeyama Islands. Ecol. Stud. Nat. Cons. Ryukyu Isl. 1: 5-36 (in Japanese).

O'NeILL K.M. \& KEMP W. P. 1992: Behavioural thermoregulation in two species of robber flies occupying different grassland microhabitats. J. Thermal Biol. 17: 323-331.

SHELly T.E. 1984: Comparative foraging behavior of Neotropical robber flies (Diptera: Asilidae). Oecologia 62: $188-195$.

SHELLY T.E. 1985: Ecological comparison of robber fly species (Diptera: Asilidae) coexisting in a neotropical forest. Oecologia 67 : 57-70.

TAKARA T. \& Azuma S. 1970: Fauna of the Iriomote Island, Ryukyus. Ryukyu Daigaku Nogakuho 17: 273-328 (in Japanese).

Received July 30, 2001; revised October 17, 2001; accepted November 13, 2001 